\title{
Effects of directly observed treatment short-course education program on the knowledge, attitude and practice of community health extension workers in the management of tuberculosis in Sagamu local government, Ogun state, southwest Nigeria
}

\author{
Adekunle Durojaiye Alabi* \\ Department of Community Medicine and Primary Care, Olabisi Onabanjo University Teaching Hospital, Sagamu, \\ Ogun State, Nigeria \\ Received: 11 March 2016 \\ Accepted: 13 April 2016 \\ *Correspondence: \\ Dr. Adekunle Durojaiye Alabi, \\ E-mail: drkalabi@yahoo.com \\ Copyright: () the author(s), publisher and licensee Medip Academy. This is an open-access article distributed under \\ the terms of the Creative Commons Attribution Non-Commercial License, which permits unrestricted non-commercial \\ use, distribution, and reproduction in any medium, provided the original work is properly cited.
}

\begin{abstract}
Background: Tuberculosis (TB) is one of the leading infectious diseases globally. Effective follow-up of TB patients is imperative for disease control. The present study assessed the effects of a directly observed treatment short course (DOTS) education program on the knowledge, attitude and practice (KAP) of community health extension workers (CHEWs) in the management of TB in Sagamu, Ogun State, Southwest Nigeria.

Methods: A controlled experimental study was carried out in three phases (pre-training, immediate post-training and three months post-training) between two groups (control and intervention groups). Data were analyzed using paired and Student's t-tests as appropriate.

Results: Pre-training assessment KAP scores were poor for CHEWs in both the control and intervention groups. There was a statistically significant increase $(p<0.05)$ in KAP of DOTS in TB management at both the immediate and three months post-training stages when compared with the pre-training stage. Comparison between the immediate and three months post-training scores showed no significant difference.

Conclusions: The education program was an effective intervention to improve the CHEW's knowledge, attitude and practice of DOTS in the management of tuberculosis. Thus, there should be frequent education of health care providers on DOTS to increase their capacities for meeting the challenges of providing care for tuberculosis patients.
\end{abstract}

Keywords: Tuberculosis, CHEW, DOTS, Sagamu

\section{INTRODUCTION}

Tuberculosis (TB) is a chronic infectious disease caused by Mycobacterium tuberculosis. Global statistics show that over 10 million people are infected with TB, and in 2013 alone, 9 million new cases were recorded. ${ }^{1}$ The TB scourge is further worsened by the HIV/AIDS epidemic, as a third of HIV/AIDS patients is co-infected with TB. ${ }^{2}$ With an annual mortality of 1.45 million deaths despite intense prevention and control campaigns, more stringent attention should be focused on monitoring and evaluation. $^{3}$ According to national tuberculosis and leprosy control program in Nigeria (NTBLCP), Nigeria is ranked among the 22 high burden countries in the world with predisposing factors including: overcrowding, poor nutrition, poverty, improper diagnosis and treatment and poor compliance. ${ }^{4,5}$ In an attempt to stem TB epidemic, the World Health Organization (WHO) introduced the Directly Observed Treatment Short course (DOTS) strategy. 6 The DOTS strategy lays emphasis on close treatment monitoring of TB. Consequently, to achieve wide coverage of National health policies, new cadres of 
health workers whose orientation tended towards the provision of health care in rural communities were developed. ${ }^{7}$ Among these cadres of workers are the Community Health Extension Workers (CHEWs). ${ }^{8}$ The CHEWs receive formal training which enables them serve as first line primary health care workers at the grass roots. ${ }^{9}$ To ensure early diagnosis and effective management of $\mathrm{TB}$, it is therefore pertinent to ascertain the level of knowledge, attitude and practice of DOTS by CHEWs.

\section{METHODS}

Study location: This study was carried out in Sagamu, Ogun state in the southwestern part of Nigeria. Sagamu is a semi-urban area with an estimated population of about 200,000 people, ${ }^{10}$ four health clinics and two Tuberculosis and Leprosy (TBL) control centers. The control subjects were obtained from Ikenne local government area also in Ogun state. Ikenne is also a semi-urban area with an estimated population of about 140,000 people, which is serviced by five health clinics. All health facilities in both local government areas provide DOTS services to TB patients.

Study population: This study was a controlled experimental study. All 112 CHEWs in the health facilities within Sagamu and Ikenne local government areas were included in the study. The 58 CHEWs in Sagamu served as the intervention group, while 54 CHEWs in Ikenne served as the control group.

Sample size: The minimum expected sample size for an observable mean difference between control and study group of $10 \%$ (0.01) or more at 0.05 level of significance was calculated using following the method. ${ }^{11}$

$$
\mathrm{n}=\frac{(\mathrm{Z} \alpha+\mathrm{Z} \beta) 22(\delta) 2}{(\mathrm{M} 1-\mathrm{M} 0) 2}
$$

Where $\mathrm{n}=$ Minimum sample size for each group.

- $\mathrm{Z} \alpha=$ standard normal deviate corresponding to $5 \%$ level $=1.96$

- $\quad \mathrm{Z} \beta=$ standard normal deviate corresponding to $20 \%$ level $=0.84$

- $\delta=$ standard deviation from previous study.

M1-M0= Minimum anticipated difference to be judged statistically significant.

$$
\begin{gathered}
\mathrm{n}=\frac{(1.96+0.84) 2_{\chi} 2(1.78) 2}{(10) 2} \\
\mathrm{n}=49.68 \approx 50
\end{gathered}
$$

The study groups therefore had the required minimum sample size of 50 subjects each; 58 CHEWs in Sagamu formed the intervention group, while 54 CHEWs in Ikenne formed the control group.
The pre-intervention (pre-training) activities included (a) obtaining official permission to proceed with the study from the Local Government Area authorities, (b) consent of the CHEWs to fully participate at all stages of the study was obtained, (c) the study questionnaire was pretested among CHEWs in another local government area and necessary corrections were made, (d) a base-line survey to determine the CHEWs knowledge, attitude and practice (KAP) of DOTS was conducted using the corrected questionnaire. This represented the pre-training assessment for the intervention group and the initial assessment for the control group.

The training program used for the study consisted of a structured educational protocol based on the Federal Ministry of Health National Tuberculosis and Leprosy Control Program (NTBLCP) revised workers manual. ${ }^{12}$ These sessions covered all aspects of the management of tuberculosis (DOTS). Participating CHEWs (intervention group) were divided into four batches with an average of 14 CHEWs each, and the training lasted two weeks.

The first post intervention evaluation was done immediately after the training (immediate post-training assessment). The second evaluation was carried out three months after the training (three months post-training assessment). Evaluation of the effects of training was done using standardize scores for the various variables during analysis. For the control group, reassessments were conducted two weeks and three months after the initial assessment.

The assessments were done using self-administered structured questionnaires. The EPI-INFO 6 statistical computer software was used for the data entry, validation and analysis. Scores were assigned to the variables evaluated. The total scores were 40 for knowledge, 16 for attitude and 10 for practice (Total=66). Measures of central tendency and dispersion were computed for variables, and means compared. The pre-training assessments were compared with the post-training assessments, while the control group was compared with the intervention group using the paired t-test. Level of significance was put at $\mathrm{p}<0.05$.

\section{RESULTS}

Mean age of the respondents was $(37.1 \pm 7.1)$ years. The male to female ratio was 1:1.6 for all respondents. Also, $74.1 \%$ of all the participants were married (Table 1). The mean years of experience were 9.2 \pm 1.2 years (Table 1 ). $68.8 \%$ of the participants had cared for TB patients prior training (35 in the intervention group and 42 in the control group) and $40.2 \%$ of the respondents were caring for TB patients during the training ( 24 in the control group and 21 in the intervention group) (Table 1). Only $23.2 \%$ of the respondents (12 of the control group and 14 of the intervention group) had received any training in DOTS management of TB prior to the training, hence, majority $97.3 \%$ considered the training necessary. 
Before the training, about $50 \%$ of participants in both groups had any knowledge of DOTS-related terms and acronyms (Tables 2 and 3). Immediately after training, knowledge increased to between $89 \%$ and $98 \%(\mathrm{p}<0.05)$ in the intervention group, and remained high three months after training (79.6\% to $96.3 \%$ ) (Table 2). The generally poor awareness pattern did not change significantly in the control group neither during second assessment nor third assessment (Table 3 ).

Table 1: Demographic distribution of respondents.

\begin{tabular}{|c|c|c|c|c|c|c|}
\hline Characteristics & & $\begin{array}{l}\text { group } \\
\%\end{array}$ & $\begin{array}{l}\text { Int } \\
(\mathbf{n}=\end{array}$ & n group & Chi-square & p-value \\
\hline $\begin{array}{l}\text { Age (years) } \\
<31 \\
31-40 \\
41-50 \\
>50\end{array}$ & $\begin{array}{l}10 \\
29 \\
11 \\
4\end{array}$ & $\begin{array}{l}18.5 \\
53.7 \\
20.4 \\
7.4\end{array}$ & $\begin{array}{l}6 \\
31 \\
17 \\
4\end{array}$ & $\begin{array}{l}10.3 \\
53.4 \\
29.3 \\
6.9\end{array}$ & 2.21 & 0.530 \\
\hline $\begin{array}{l}\text { Sex } \\
\text { Male } \\
\text { Female }\end{array}$ & $\begin{array}{l}24 \\
30\end{array}$ & $\begin{array}{l}44.4 \\
55.6\end{array}$ & $\begin{array}{l}20 \\
38\end{array}$ & $\begin{array}{l}34.5 \\
65.5\end{array}$ & 1.16 & 0.281 \\
\hline $\begin{array}{l}\text { Marital status } \\
\text { Single } \\
\text { Married }\end{array}$ & $\begin{array}{l}17 \\
37\end{array}$ & $\begin{array}{l}31.5 \\
68.5\end{array}$ & $\begin{array}{l}12 \\
46\end{array}$ & $\begin{array}{l}20.7 \\
79.3\end{array}$ & 1.70 & 0.193 \\
\hline $\begin{array}{l}\text { Years of experience } \\
<1 \\
1-5 \\
6-10 \\
11-15 \\
16-20 \\
>20\end{array}$ & $\begin{array}{l}5 \\
13 \\
18 \\
8 \\
2 \\
8\end{array}$ & $\begin{array}{l}9.3 \\
24.1 \\
33.3 \\
14.8 \\
3.7 \\
14.8\end{array}$ & $\begin{array}{l}0 \\
7 \\
24 \\
9 \\
6 \\
12\end{array}$ & $\begin{array}{l}0.0 \\
12.21 \\
41.4 \\
15.5 \\
10.3 \\
20.7\end{array}$ & 10.39 & 0.065 \\
\hline $\begin{array}{l}\text { Cared for TB patient(s)in the pa } \\
\text { Yes } \\
\text { No }\end{array}$ & $\begin{array}{l}42 \\
12 \\
\end{array}$ & $\begin{array}{l}77.8 \\
22.2\end{array}$ & $\begin{array}{l}35 \\
20\end{array}$ & $\begin{array}{l}63.6 \\
36.4 \\
\end{array}$ & 2.627 & 0.105 \\
\hline $\begin{array}{l}\text { Caring for TB patient(s) now } \\
\text { Yes } \\
\text { No }\end{array}$ & $\begin{array}{l}24 \\
30\end{array}$ & $\begin{array}{l}44.4 \\
55.6\end{array}$ & $\begin{array}{l}21 \\
36\end{array}$ & $\begin{array}{l}36.8 \\
63.2\end{array}$ & 0.665 & 0.415 \\
\hline
\end{tabular}

Table 2: Awareness of dots-related acronyms in intervention group.

\begin{tabular}{|c|c|c|c|c|c|c|c|}
\hline \multirow[t]{2}{*}{$\begin{array}{l}\text { DOTS-related terms and } \\
\text { acronyms }\end{array}$} & \multicolumn{2}{|c|}{$\begin{array}{l}\text { Pre-training } \\
\text { assessment } \\
(\mathbf{n}=\mathbf{5 8})\end{array}$} & \multicolumn{2}{|c|}{$\begin{array}{l}\text { Immediate post- } \\
\text { training evaluation } \\
(\mathrm{n}=58)\end{array}$} & \multicolumn{2}{|c|}{$\begin{array}{l}\text { Three months } \\
\text { post-training } \\
\text { evaluation }(n=54)\end{array}$} & \multirow[t]{2}{*}{ p-value } \\
\hline & $\mathrm{f}$ & $\%$ & $\mathrm{f}$ & $\%$ & $\mathrm{f}$ & $\%$ & \\
\hline AAFB & 15 & 25.9 & 54 & 93.1 & 47 & 87 & $\mathrm{P}=0.000^{*}, \mathrm{P}=0.149$ \\
\hline Short course chemotherapy & 15 & 25.9 & 54 & 93.1 & 47 & 87 & $\mathrm{P}=0.000^{*}, \mathrm{P}=0.149$ \\
\hline BCG & 38 & 65.5 & 56 & 96.6 & 52 & 96.3 & $\mathrm{P}=0.000^{*}, \mathrm{P}=1.580$ \\
\hline Contact tracing & 17 & 29.3 & 55 & 94.8 & 51 & 94.4 & $\mathrm{P}=0.000^{*}, \mathrm{P}=0.944$ \\
\hline Treatment failure & 17 & 29.3 & 55 & 94.8 & 51 & 94.4 & $\mathrm{P}=0.000^{*}, \mathrm{P}=0.944$ \\
\hline Defaulter & 17 & 29.3 & 55 & 94.8 & 51 & 94.4 & $\mathrm{P}=0.000^{*}, \mathrm{P}=0.944$ \\
\hline Isoniazid & 35 & 60.3 & 56 & 96.6 & 51 & 94.4 & $\mathrm{P}=0.000^{*}, \mathrm{P}=0.818$ \\
\hline Tubercle bacillus & 30 & 51.7 & 57 & 98.3 & 51 & 94.4 & $\mathrm{P}=0.000^{*}, \mathrm{P}=0.181$ \\
\hline Rifampicin & 32 & 55.2 & 57 & 98.3 & 52 & 96.3 & $\mathrm{P}=0.000^{*}, \mathrm{P}=0.817$ \\
\hline Intensive phase & 15 & 25.9 & 56 & 96.6 & 51 & 96.3 & $\mathrm{P}=0.000^{*}, \mathrm{P}=0.821$ \\
\hline Continuation phase & 15 & 25.9 & 56 & 96.6 & 51 & 96.3 & $\mathrm{P}=0.000^{*}, \mathrm{P}=0.821$ \\
\hline Mantoux & 36 & 62.1 & 57 & 98.3 & 51 & 96.3 & $\mathrm{P}=0.000^{*}, \mathrm{P}=0.817$ \\
\hline DOTS & 7 & 12.1 & 52 & 89.6 & 43 & 79.6 & $\mathrm{P}=0.000^{*}, \mathrm{P}=0.667$ \\
\hline Drug compliance & 27 & 46.6 & 53 & 91.3 & 51 & 94.4 & $\mathrm{P}=0.000^{*}, \mathrm{P}=0.590$ \\
\hline
\end{tabular}

$\mathrm{f}=$ frequency, upper $\mathrm{p}$-value compares pre-training assessment with immediate post-training evaluation. Lower $\mathrm{p}$-value compares immediate and three months post-training valuation. ${ }^{*}=$ statistically significant. 
Table 3: Awareness of DOTS-related acronyms in control group.

\begin{tabular}{|c|c|c|c|c|c|c|c|}
\hline \multirow[t]{2}{*}{$\begin{array}{l}\text { DOTS-related terms and } \\
\text { acronyms }\end{array}$} & \multicolumn{2}{|c|}{$\begin{array}{l}\text { Pre-training } \\
\text { Assessment }(n=54)\end{array}$} & \multicolumn{2}{|c|}{$\begin{array}{l}\text { Immediate post- } \\
\text { training evaluation } \\
(\mathrm{n}=54)\end{array}$} & \multicolumn{2}{|c|}{$\begin{array}{l}\text { Three months } \\
\text { post-training } \\
\text { evaluation }(n=52)\end{array}$} & \multirow[t]{2}{*}{ p-value } \\
\hline & $\mathrm{f}$ & $\%$ & $\mathrm{f}$ & $\%$ & $\mathrm{f}$ & $\%$ & \\
\hline AAFB & 12 & 22.2 & 14 & 25.9 & 12 & 23.1 & $\begin{array}{l}\mathrm{P} 1=0.155 \\
\mathrm{P} 2=0.134\end{array}$ \\
\hline Short course chemotherapy & 12 & 22.2 & 14 & 25.9 & 12 & 23.1 & $\begin{array}{l}\mathrm{P} 1=0.155 \\
\mathrm{P} 2=0.134\end{array}$ \\
\hline BCG & 39 & 72.2 & 38 & 70.4 & 36 & 69.2 & $\begin{array}{l}\mathrm{P} 1=0.556 \\
\mathrm{P} 2=0.580\end{array}$ \\
\hline Contact tracing & 14 & 25.9 & 12 & 22.2 & 12 & 23.1 & $\begin{array}{l}\mathrm{P} 1=0.667 \\
\mathrm{P} 2=0.768\end{array}$ \\
\hline Treatment failure & 14 & 25.9 & 12 & 22.2 & 12 & 23.1 & $\begin{array}{l}\mathrm{P} 1=0.667 \\
\mathrm{P} 2=0.768\end{array}$ \\
\hline defaulter & 14 & 25.9 & 12 & 22.2 & 12 & 23.1 & $\begin{array}{l}\mathrm{P} 1=0.667 \\
\mathrm{P} 2=0.768\end{array}$ \\
\hline Isoniazid & 32 & 59.3 & 30 & 55.6 & 28 & 53.8 & $\begin{array}{l}\mathrm{P} 1=0.812 \\
\mathrm{P} 2=0.818\end{array}$ \\
\hline Tubercle bacillus & 30 & 55.6 & 30 & 55.6 & 30 & 57.7 & $\begin{array}{l}\mathrm{P} 1=0.148 \\
\mathrm{P} 2=0.181\end{array}$ \\
\hline Rifampicin & 28 & 51.9 & 29 & 53.7 & 27 & 51.9 & $\begin{array}{l}\mathrm{P} 1=0.822 \\
\mathrm{P} 2=0.817\end{array}$ \\
\hline Intensive phase & 16 & 29.6 & 16 & 29.6 & 13 & 25.0 & $\begin{array}{l}\mathrm{P} 1=0.811 \\
\mathrm{P} 2=0.821\end{array}$ \\
\hline Continuation phase & 16 & 29.6 & 16 & 29.6 & 13 & 25.0 & $\begin{array}{l}\mathrm{P} 1=0.811 \\
\mathrm{P} 2=0.821\end{array}$ \\
\hline Mantoux & 34 & 62.9 & 36 & 66.7 & 34 & 65.4 & $\begin{array}{l}\mathrm{P} 1=0.834 \\
\mathrm{P} 2=0.817\end{array}$ \\
\hline DOTS & 4 & 7.4 & 5 & 9.3 & 4 & 7.7 & $\begin{array}{l}\mathrm{P} 1=0.611 \\
\mathrm{P} 2=0.667\end{array}$ \\
\hline Drug compliance & 24 & 44.4 & 26 & 48.1 & 21 & 40.4 & $\begin{array}{l}\mathrm{P} 1=0.582 \\
\mathrm{P} 2=0.590\end{array}$ \\
\hline
\end{tabular}

$\mathrm{f}=$ frequency, $\mathrm{P} 1$-value compares pre-training assessment with immediate post-training evaluation. P2-value compares immediate and three months post-training valuation. $*=$ statistically significant.

The mean scores for knowledge of DOTS in the control and intervention groups were $16.00 \pm 1.2$ and $16.32 \pm 1.4$ with the mean difference of 0.32 . This highlights the similar level of DOTS knowledge in both groups prior to the implementation of the program. Comparison of the two post-training evaluation stages (in the intervention group) did not show any significant difference. In the control group, there was no appreciable improvement in the knowledge of respondents during the three assessments (Tables 4 and 5).

More than half of the respondents $51.8 \%$ had a negative attitude to DOTS prior to training; 28 of these 58 were from the control while the remaining 30 were from the intervention group (Tables 4 and 5). Prior to the training program, all participants $(100 \%)$ showed bad practice of DOTS (Tables 4 and 5). There was no statistically significant difference in the level of knowledge of participants, attitude to DOTS and practice of DOTS in the control group at subsequent evaluations, while there were statistically significant improvements in the intervention group (Table 6).

Table 4: Baseline distribution of perception.

\begin{tabular}{|lllll|}
\hline & \multicolumn{2}{c}{ Control } & \multicolumn{2}{c|}{ Intervention } \\
\hline Scores & $\mathrm{f}$ & $\%$ & $\mathrm{f}$ & $\%$ \\
\hline knowledge & & & & \\
\hline $0-9$ & 2 & 3.7 & 2 & 3.5 \\
$10-19$ & 32 & 59.3 & 35 & 61.4 \\
$20-29$ & 15 & 27.8 & 14 & 24.6 \\
$30-39$ & 5 & 9.2 & 6 & 10.5 \\
\hline Attitude & & & & \\
\hline $0-7$ & 28 & 51.9 & 30 & 51.7 \\
$8-16$ & 26 & 48.1 & 27 & 48.3 \\
\hline Practice & & & & \\
\hline $0-9$ & 54 & 100 & 57 & 100 \\
$10-20$ & 0 & 0 & 0 & 0 \\
\hline
\end{tabular}


The mean perception scores at pre-, immediate post- and three months post-intervention for the control and intervention groups are shown in Table 7. The mean difference of changes in knowledge of DOTS was 15.22
( $\mathrm{p}=0.000)$, attitude to DOTS was $4.77(\mathrm{p}=0.000)$ and practice of DOTS was $4.42(\mathrm{p}=0.000)$ between the control and intervention groups (Table 8).

Table 5: Baseline scores.

\begin{tabular}{|c|c|c|c|c|c|c|}
\hline & Group & $\begin{array}{l}\text { Mean } \\
\text { score }\end{array}$ & $\begin{array}{l}\% \text { of total } \\
\text { score }\end{array}$ & Mean difference & $\mathbf{t}$ & p-value \\
\hline $\begin{array}{l}\text { Knowledge } \\
(\text { total }=40)\end{array}$ & $\begin{array}{l}\text { Control } \\
\text { Intervention }\end{array}$ & $\begin{array}{l}16.00 \\
16.32\end{array}$ & $\begin{array}{l}40.0 \\
40.8\end{array}$ & 0.32 & -1.668 & 0.120 \\
\hline $\begin{array}{l}\text { Attitude } \\
\text { (total=16) }\end{array}$ & $\begin{array}{l}\text { Control } \\
\text { Intervention }\end{array}$ & $\begin{array}{l}7.46 \\
7.54\end{array}$ & $\begin{array}{l}46.6 \\
47.2\end{array}$ & 0.08 & -1.436 & 0.150 \\
\hline $\begin{array}{l}\text { Practice } \\
\text { (total }=10)\end{array}$ & $\begin{array}{l}\text { Control } \\
\text { Intervention }\end{array}$ & $\begin{array}{l}3.96 \\
3.56\end{array}$ & $\begin{array}{l}39.6 \\
35.6\end{array}$ & 0.40 & 1.208 & 0.230 \\
\hline
\end{tabular}

Table 6: Pre and post-intervention scores.

\begin{tabular}{|c|c|c|c|c|c|}
\hline & Mean difference & Standard deviation & Paired $t$ & p-value & $95 \% \mathrm{CI}^{*}$ \\
\hline \multicolumn{6}{|c|}{ Control group } \\
\hline Knowledge & -0.20 & 2.010 & -0.70 & 0.485 & $-0.37-0.77$ \\
\hline Attitude & 0.04 & 0.989 & 0.29 & 0.776 & $-0.32-0.24$ \\
\hline Practice & 0.08 & 0.853 & 0.66 & 0.510 & $-0.32-0.16$ \\
\hline \multicolumn{6}{|c|}{ Intervention group } \\
\hline Knowledge & 15.02 & 7.46 & 14.79 & 0.000 & $12.98-17.06$ \\
\hline Attitude & 4.82 & 3.25 & 10.88 & 0.000 & $3.93-5.70$ \\
\hline Practice & 4.50 & 2.16 & 15.30 & 0.000 & $3.91-5.09$ \\
\hline
\end{tabular}

Table 7: Comparison of changes in the groups.

\begin{tabular}{|llllll|}
\hline & Mean difference & Standard deviation & Paired t & p-value & 95\% CI* \\
\hline Control group & \multicolumn{2}{c|}{} \\
\hline Knowledge & -0.20 & 2.010 & -0.70 & 0.485 & $-0.37-0.77$ \\
Attitude & 0.04 & 0.989 & 0.29 & 0.776 & $-0.32-0.24$ \\
Practice & 0.08 & 0.853 & 0.66 & 0.510 & $-0.32-0.16$ \\
\hline Intervention group & & & & & \\
\hline Knowledge & 15.02 & 7.46 & 14.79 & 0.000 & $12.98-17.06$ \\
Attitude & 4.82 & 3.25 & 10.88 & 0.000 & $3.93-5.70$ \\
Practice & 4.50 & 2.16 & 15.30 & 0.000 & $3.91-5.09$ \\
\hline
\end{tabular}

Table 8: Comparison of means of the groups.

\begin{tabular}{|lllll|} 
& $\begin{array}{l}\text { Mean } \\
\text { Difference }\end{array}$ & t & p-value & 95\% CI \\
Knowledge & 15.22 & 13.96 & 0.000 & $13.06-17.38$ \\
\hline Attitude & 4.77 & 9.96 & 0.000 & $3.82-5.72$ \\
\hline Practice & 4.42 & 13.52 & 0.000 & $3.77-5.07$ \\
\hline
\end{tabular}

*CI= confidence interval

There were still significant differences in the knowledge, attitude and practice of DOTS between the control and intervention groups even after adjusting for sex, age, marital status, years of experience and previous experience in the management of TB patients (Table 9).
Table 9: Adjusted mean differences between the control and intervention groups.

\begin{tabular}{|llll|}
\hline & $\begin{array}{l}\text { Mean } \\
\text { difference }\end{array}$ & $\begin{array}{l}\text { p- } \\
\text { value }\end{array}$ & 95\% CI \\
\hline Knowledge & 7.960 & 0.000 & $7.004-8.915$ \\
\hline Attitude & 2.546 & 0.000 & $2.159-2.933$ \\
\hline Practice & 2.298 & 0.000 & $1.998-2.598$ \\
\hline
\end{tabular}

${ }^{*} \mathrm{CI}=$ confidence interval

\section{DISCUSSION}

Community Health Extension Workers (CHEWs) were recruited soon after the introduction of DOTS into the Nigerian healthcare system. ${ }^{5}$ At this time, the country's 
response to TB was still evolving and health training programs had not fully incorporated DOTS into their curricula. It is therefore unlikely that most of the participants received adequate formal instruction on DOTS in the management of TB. Majority (68.8\%) of the CHEWs had cared for TB patients prior to the training and $45 \%$ of them were currently doing so at the time of this training. This suggests that majority of the CHEWs had cared for TB patients without adequate knowledge. This is possibly one major reason why TB control in the country has remained ineffective. ${ }^{4,13,14}$ The relative lack of professional preparation in DOTS management of TB was probably an important factor why virtually all the participants $(97.3 \%)$ considered the proposed training necessary.

Before the educational intervention, the participants in both groups had low knowledge on all areas pertinent to the subject of DOTS in TB. Similar results have been reported among medical interns in other countries who showed poor knowledge of DOTS prior to appropriate training. ${ }^{15,16}$ At the end of the training, there was significant increase in all aspects of DOTS-related knowledge in the intervention group much of which was still retained three months after the training. These findings suggest that once appropriately trained, health workers are likely to comply to the principles of DOTS in TB management, as has been suggested by others. ${ }^{17-19}$

Prior to training, less than $50 \%$ of the control and intervention groups could accurately define a TB case, correctly identify new cases of TB or define the duration of phases of DOTS. Interestingly, by the end of the educational intervention, $92 \%$ to $96 \%$ of the intervention group could correctly outline the treatment phases of DOTS $(\mathrm{p} \leq 0.02)$. There was no appreciable improvement in the knowledge of the control group throughout the duration of the study.

More than half of the respondents $(51.9 \%$ in control and $51.7 \%$ in the intervention group) had a negative attitude to DOTS at the start of the study. Such attitudes have been reported in previous studies. ${ }^{18}$ Before intervention, majority of the participants believed that TB was curable but were not sure whether DOTS was effective. Reasons given by CHEWs for their attitude on DOTS included: non-availability of drugs $(55 \%)$, long duration of drug use $(63 \%)$, delay in getting result from the laboratory $(22 \%)$ and inadequate qualified workers to take care of patients $(8 \%)$. Some participants felt that TB patients were not getting the best management from DOTS. The post intervention evaluation indicated positive changes in the attitude of the CHEWs to DOTS, while there was no significant change in attitude in the control group.

All $(100 \%)$ of the participants showed very poor practice of DOTS in the management of TB patients in the pretraining phase. This generally poor performance rating in the overall DOTS-related practice on management of TB is probably an accurate reflection of actual workplace practice of the participants. There was however a statistically significant improvement in the practice of DOTS in the intervention group during the intermediate and three months post-intervention evaluations ( $\mathrm{p}=$ 0.000). No such improvement was observed in the control group as participants still showed poor practice of DOTS during and after the study.

Significant results were obtained for the changes in the intervention group but not in the control group. Even after adjusting for variables such as sex, age, marital status and years of experience, there was still a significant difference between the control and intervention groups concerning the management of TB using the DOTS method.

\section{CONCLUSION}

The education program was an effective intervention to improve the CHEW's knowledge, attitude and practice of DOTS in the management of tuberculosis. Thus, there should be frequent education of health care providers on DOTS to increase their capacities for meeting the challenges of providing care for tuberculosis patients. The difference observed between the two groups was due to the effect of an educational training on DOTS received by the intervention group. Thus, well-designed frequent education of CHEWs is essential to give them adequate knowledge of DOTS in the management of TB. This would inculcate appropriate attitudes and skills in the care of TB patients; ensure effective control of TB in the country and thus the achievement of one of the millennium development goals. Based on the findings of this study, recommendations would therefore be directed to the stakeholders at the three levels of health care delivery system in Nigeria; Local governments should conduct educational programs on the management of TB by DOTS, ensure effective supervision of workers and provide logistic support to ensure effective control. State governments should ensure that CHEWs are exposed to trainings by giving adequate support to TB and leprosy control programs. They should also put in place effective information systems to monitor TB-related cases in the state and provide adequate and competent human resources. Federal government should ensure adequate support to the state and local governments by providing free treatment for TB and making the study of DOTS a compulsory part of the curricula in all approved institutions for the training of CHEWs.

\section{ACKNOWLEDGEMENTS}

The author acknowledges the support of the Sagamu and Ikenne Local Government Health Authorities. The cooperation of the Community Health Extension Workers is appreciated. The community health extension workers in Ikenne local government were also trained at the completion of the study.

Funding: No funding sources 
Conflict of interest: None declared

Ethical approval: Ethical approval was obtained from the Health departments of Sagamu and Ikenne Local Governments. Informed consent was obtained from all respondents before administering the questionnaires and strict confidentiality of all information and results was maintained.

\section{REFERENCES}

1. Dirlikov E, Raviglione M, Scano F. Global tuberculosis control: toward the 2015 targets and beyond. Ann Intern Med. 2015;163(1):52-8.

2. Molicotti P, Bua A, Zanetti S. Cost-effectiveness in the diagnosis of tuberculosis: choices in developing countries. Journal of Infection in Developing Countries. 2014;24-38.

3. Chatterjee D, Pramanik AK. Tuberculosis in the African continent: a comprehensive review. Pathophysiology. 2015;22(1):73-83.

4. Dim CC, Dim NR, Morkve O. Tuberculosis: a review of current concepts and control programme in Nigeria. Niger J Med. 2011;20(2):200-6.

5. Otu AA. A review of the national tuberculosis and leprosy control programme (NTBLCP) of Nigeria: Challenges and prospects. Ann Trop Med Public Heal. 2013;6(5):491-502.

6. Raviglione MC, Pio A. Evolution of WHO policies for tuberculosis control 1948-2001. Lancet. 2002;775-80.

7. Bamisaiye A, Olukoya A, Ekunwe EO, Abosede OA. A village health worker programme in Nigeria. World Health Forum. 1989;10(3-4):386-92.

8. Onwuhafua PI, Kantiok C, Olafimihan O, Shittu OS. Knowledge, attitude and practice of family planning amongst community health extension workers in Kaduna State, Nigeria. J Obstet Gynaecol. 2005;25(5):494-9.

9. Ordinioha B, Onyenaporo C. Experience with the use of community health extension workers in primary care, in a private rural health care institution in South Nigeria. Ann Afr Med. 2010;9(4):240-5.

10. Fetuga MB, Ogunlesi TA, Adekanmbi AF, Alabi AD. Nutritional Status of Semi-Urban Nigerian
School Children using the 2007 WHO Reference Population. West Afr J Med. 2011;30(5):331-6.

11. Khan MA, Walley JD, Witter SN, Imran A, Safdar N. Costs and cost-effectiveness of different DOT strategies for the treatment of tuberculosis in Pakistan. Directly Observed Treatment. Health Policy Plan. 2002;17(2):178-86.

12. Federal ministry of Health. National Tuberculosis and Leprosy Control Programme (NTBLCP) revised workers manual. 1998.

13. Ukwaja KN, Alobu I, Nweke CO, Onyenwe EC. Healthcare-seeking behavior, treatment delays and its determinants among pulmonary tuberculosis patients in rural Nigeria: a cross-sectional study. BMC Heal Serv Res. 2013;13:25.

14. Ibrahim LM, Hadejia IS, Nguku P, Dankoli R, Waziri NE, Akhimien MO, et al. Factors associated with interruption of treatment among pulmonary tuberculosis patients in plateau state, Nigeria 2011. Pan Afr Med J. 2014;17:78.

15. Khan JA, Zahid S, Khan R, Hussain SF, Rizvi N, Rab A, et al. Medical interns knowledge of TB in Pakistan. Trop Doct. 2005;35(3):144-7.

16. Charkazi AR, Kouchaki G, Nejad MS, Gholizade AH. Medical interns' knowledge of tuberculosis and DOTS strategy in northern Islamic Republic of Iran. East Mediterr Heal J. 2010;16(12):1251-6.

17. Kanjee Z, Catterick K, Moll AP, Amico KR, Friedland GH. Tuberculosis infection control in rural South Africa: survey of knowledge, attitude and practice in hospital staff. J Hosp Infect. 2011;79(4):333-8.

18. Sagare SM, Bogam RR, Murarkarsujata SK, Patil UP, Ghate MM. Knowledge, attitude and practices of ASHAs regarding tuberculosis and DOTS. Indian J Sci Technol. 2012;5(3):2401-4.

19. Yimer SA, Holm-Hansen C, Bjune GA. Assessment of knowledge and practice of private practitioners regarding tuberculosis control in Ethiopia. J Infect Dev Ctries. 2012;6(1):13-9.

Cite this article as: Alabi AD. Effects of directly observed treatment short-course education program on the knowledge, attitude and practice of community health extension workers in the management of tuberculosis in Sagamu local government, Ogun state, southwest Nigeria. Int J Community Med Public Health 2016;3:1261-7. 